\title{
Prevalence and Characterization of Salmonella Isolates from Poultry Farms in Ilorin, Nigeria
}

\author{
Shola K. Babatunde ${ }^{1} \rtimes$ \\ Deboye O. Kolawole ${ }^{2}$ \\ Majekodunmi R. Adedayo ${ }^{3}$ \\ Adeyinka E. Ajiboye ${ }^{4}$ \\ Abudllahai T. Ajao 5 \\ Omolara N. Mustapha ${ }^{6}$
}

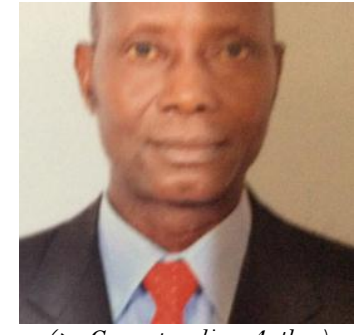

( Corresponding Author)

${ }^{1,2,9,3,5,5,0}$ Department of Biosciences and Biotechnology, College of Pure and Applied Sciences, Krwara State of University, Malete, Nigeria

\begin{abstract}
Poultry birds are very important source of essential proteins in developing countries, but also play an important role in transmission of Salmonella to human and nonhuman. Exposure to this pathogen also occurs through use of poultry droppings as manure for crop and vegetable production. This study investigated prevalence of Salmonella in feces of poultry farms in Ilorin, Nigeria. Salmonella isolated were further characterized by molecular method. Fecal samples were cultured in pre-enrichment medium, Selenite F medium and finally sub-cultured on SalmonellaShigella agar. None lactose fermenting colonies with black center were picked for presumptive identification using biochemical tests and confirmed by serological test by method previously described. Molecular characterization was carried out using 16S rRNA gene sequencing following standard procedure. Out of 170 samples collected and examined, 8 (4.7\%) gave biochemical characteristics that resembled Salmonella, but only $6(3.5 \%)$ were confirmed as Salmonella by polyvalent antisera. Molecular characterization revealed that serovars isolated were Salmonella Enteritidis $3(1.8 \%)$ and Salmonella Paratyphi 3 (1.8\%). Phylogenetic tree constructed by neighbor-joining method as derived from analysis of the 16S rRNA gene sequences showed close relationship to Salmonella Paratyphi strain FBo015 16S ribosoma RNA gene partial sequence to our Salmonella Paratyphi isolates. The detection of 3.5\% prevalence rate of Salmonella serovar from feces of laying poultry birds my serve as potential source of transmission of this pathogen to human through chicken meat, egg or use of poultry dropping as manure in crop or vegetable production.
\end{abstract}

Keywords: Salmonella, Poultry, Serovars, Genetic relatedness, Faeces.

Citation | Shola K. Babatunde; Deboye O. Kolawole; Majekodunmi R. Adedayo; Adeyinka E. Ajiboye; Abudllahai T. Ajao; molara N. Mustapha (2017). Prevalence and Characterization of Salmonell Isolates from Poultry Farms in Ilorin, Nigeria. Journal of Life Sciences Research, 4(1): 1-4. History:

Received: 2 February 2017 Revised: 24. March 2017 Accepted: 30 March 2017 Published: 5 April 2017

Licensed: This work is licensed under a Creative Commons Attribution 3.0 License $(\mathrm{coc})$

Publisher:Asian Online Journal Publishing Group
Contribution/Acknowledgement: Permission for this study was obtained from PAN (Poultry Association of Nigeria) Kwara State, and the study was approved by Community Development Center of Kwara State University, Malete. We thank the technical staff of Microbiology Laboratory Mrs. Debora Gabriel and Mrs. Anu Mohammed for their assistance.

Funding: This study received no specific financial support.

Competing Interests: The authors declare that they have no conflict of interests.

Transparency: The authors confirm that the manuscript is an honest, accurate, and transparent account of the study was reported; that no vital features of the study have been omitted; and that any discrepancies from the study as planned have been explained.

Ethical: This study follows all ethical practices during writing

\section{Contents}

\section{Introductio}

2. Materials and Methods

3. Results

4. Discussions

5. Conclusion

References 


\section{Introduction}

Salmonella is a ubiquitous and hardly bacteria capable of surviving in dry and wet environments. It is a prominent member of the family Enterobacteriaceae that consists of more than 2,500 different strains [1]. While a few serotypes are host specific and can reside in only one or few animal species, others have a wide range of hosts. Some Salmonella have been considered as one of the most important food-borne pathogen around the world $[1,2]$.

Salmonellosis is often associated with gastroenteritis; characterized by acute onset of fever, abdominal pain, diarrhea, nausea and sometimes vomiting. The organism can seep into the blood stream causing bacteremia and typhoid fever. Salmonellosis is one of the most common and widely distributed foodborne diseases, with tens of millions of human cases occurring worldwide per annum [1]. In tropics especially in sub-Saharan Africa, nontyphoidal salmonella has consistently been reported as leading causes of bacteremia and gastroenteritis among elderly, malnourished children, infants and immunocompromised individuals [3].

Poultry farming is one of the major sources of meat protein in Nigeria, where large scale farms with thousands of birds exist, others have few hundred birds. They serve as major source of animal protein either as meat or egg. Contamination of poultry birds arise from either contamination of feeds or water resulting in contamination of feces, litters, eggs and chicken parts which may be source of human acquisition of the infection. The sources and mode of transmission of Salmonella in developing countries are poorly understood and may be difficult to trace, due to lack of coordinated national surveillance system, poor supervision of farms and animal feed by authorities concerned [4].

While poultry droppings are very useful as manure for crop and vegetable production, they can also serve as vehicle of spread of infectious diseases to human. Previous studies on Salmonella from poultry droppings in Nigeria are limited to certain geographic region or state of the federating units and may not be a representative of other regions or states. This study aimed at bridging this gap, and also at investigating prevalence of Salmonella species in the feces of poultry birds in Ilorin, Kwara State Nigeria.

Previous studies have shown that Salmonella species have different disease syndromes and host specificity according to their antigenic profile [3]. Therefore it is expedient to discriminate Salmonella serovars isolates from each other. This will ensure that each serovar can be tracked in case of epidemics, outbreak detection or general surveillance. For this reason molecular characterization was further carried out after cultural isolation, biochemical identification and serologic confirmation in this study.

\section{Materials and Methods}

\subsection{Sample Collection}

A total of 170 poultry fecal samples were collected from three medium size farms with appropriately one thousand $(1,000)$ to one thousand two hundred $(1,200)$ laying birds in an intensive confinement. The samples were collected within a period of three months (July to September, 2016). Ninety (90) samples were collected from Kwara State University farm (Moro LGA), and forty (40) each from two farms in Tanke (Ilorin South LGA), identified as Tanke A and Tanke B farms. Representative of freshly passed fecal samples were randomly collected with a spoon attached to the cap of sterile plastic bottles. Approximately 7-8 grams of the samples were collected and arranged in ice pack glostyle bag and transported to Microbiology laboratory of Kwara State University, Malete.

\subsection{Sample Analyses}

About 4 grams of fecal sample was inoculated into pre-enriched $50 \mathrm{~mL}$ buffered peptone (Lab M Ltd, Quest Park, Bl97JJ, UK) in a $100 \mathrm{~mL}$ flask, a modification of method described by Antunes, et al. [5]. This was incubated at $37^{\circ} \mathrm{C}$ for 18 hours in ambulant air. One milliliter was sub-cultured into $10 \mathrm{~mL}$ of Selenite F broth (Lab M Ltd, Topley House, BL96AS, UK) and re-incubated at $37^{\circ} \mathrm{C}$ for another 18 hours. It was further sub-cultured onto Salmonella-Shigella and MacConkey agar (Lab M Ltd, Topley House Bl96AS, UK) for another 18 hours at $37^{\circ} \mathrm{C}$. None lactose fermenting colonies with black center were picked for presumptive identification using biochemical tests and confirmed by serological test using polyvalent antisera (Oxoid Ltd, UK) as previous described by both Forbes, et al. [6] and Barrow and Feltham [7].

Salmonella isolates were characterized by molecular method using 16S rRNA gene sequencing. The genomic DNA of each isolate was extracted using commercial DNA isolation kit (Real Biogenomics, UK) following the instruction manual of the manufacturer. The $16 \mathrm{~S}$ rRNA gene of the target isolates were amplified by using universal eubacterial primer as reported by Heddi, et al. [8].

Table-1. Base sequences of $16 \mathrm{~S}$ rRNA gene primers

\begin{tabular}{l|l|l}
\hline Name of the Primer & & Sequence (5’ to 3’) \\
\hline 16S rRNA gene & F & AGA GTT TGA TCA TGG CTC AG \\
\hline & R & TAC CTT GTT ACG ACT TCA CC \\
\hline Source: Sigma, Pvt. Ltd
\end{tabular}

The amplified PCR products were resolved by electrophoresis using one percent agarose gel in Tris acetate EDTA buffer. Agarose gel was mixed with ethidium bromide $(0.5 \mu \mathrm{g} / \mathrm{ml})$ before pouring. One kb DNA ladder (Bangalore Genei) was used as a marker. The gel was run at run at $120 \mathrm{~V}$ for 45 minutes using Bangalore Genei power Pac System (USA). Ethidium bromide stained gel was viewed images captured using gel documentation system (Alphalmager, 2200, Alpha Infotech Corporation, USA).

\subsection{Agarose Gel Electrophoresis of PCR Products}

The amplified PCR products were resolved by electrophoresis using 1 per cent agarose gel in $1 \mathrm{X}$ Tris acetate EDTA buffer (2 M Tris base, $57.10 \mathrm{ml}$ acetic acid and 0.5 M EDTA, pH 8.0, 50 X). Agarose gel was mixed with ethidium bromide $(0.5 \mu \mathrm{g} / \mathrm{ml}$ ) before pouring. $1 \mathrm{~kb}$ DNA ladder (Bangalore Genei) was used as a marker. The gel was run at $120 \mathrm{~V}$ for 45 minutes using Bangalore Genei Power Pac system. The ethidium bromide stained gel was 
viewed and image captured using gel documentation system (Alphalmager 2200, Alpha Infotech Corporation, USA).

\subsection{Sequencing and Data Analysis}

PCR products of $16 \mathrm{~S}$ rRNA gene of six efficient bacterial isolates obtained through amplification with specific primer were freeze dried in a lyophilizer (CHRIST ALPHA I-2LD) sequenced using same upstream and downstream primers used for the amplification of $16 \mathrm{~S}$ rRNA gene (Ocimum Biosolutions, Pvt. Ltd.).

\subsection{Nucleotide Sequence Analysis}

The $16 \mathrm{~S}$ rDNA sequences of different bacterial isolates were BLAST (Basic local alignment search tool) searched against the sequences of $16 \mathrm{~S}$ rRNA of bacterial isolates available in the Genbank Nucleotide Database Sequences with more than $98 \%$ identify with a GenBank sequence were considered to be of the same species as the highest score-matching sequence on the public sequence databases as in Altschul, et al. [9] for sequence comparison. The sequences were aligned by Clustal W program using website [10] and pair wise per cent nucleotide sequence similarities between isolates 3 and 3 isolates and other selected bacterial sequences from NCBI database were determined. Phylogenetic analysis was performed with neighbor-joining method using program in Molecular Evolutionary Genetics Analysis (MEGA) version 5.1 [11].

\section{Results}

Out of 170 fecal dropping samples collected and cultured for Salmonella, 8 were presumptively identified as Salmonella by biochemical methods and $6(3.5 \%)$ of were confirmed with serologic method to be Salmonella serovar. Samples distribution and Salmonella isolation was as presented in Table 2.

Table-2. Showing distribution of Salmonella isolates among the three farms

\begin{tabular}{l|l|l}
\hline & No of samples (\%) & No Positive for Salmonella (\%) \\
\hline KWASU & $90(52.9)$ & $3(3.3)$ \\
\hline Tanke A & $40(23.5)$ & $2(5.0)$ \\
\hline Tanke B & $40(23.5)$ & $1(2.5)$ \\
\hline Total & $170(100)$ & $6(3.5)$ \\
\hline Source: This was generated from sample collection sources
\end{tabular}

The molecular characterization of nucleotide sequence analysis revealed that the strains isolated were 3 Salmonella Enteritidis and 3 Salmonella Paratyphi in the $99 \%$ and $100 \%$ homogeneity respectively.

\subsection{Nucleotide Sequence Analysis}

Nucleotide sequence analysis of test isolates using clustalW program revealed that isolates 3 showed maximum homology (100\%) with Salmonella Paratyphi strain FBD 0015 (EF 643617.1), isolate 3 showed homology (99\%) with Salmonella Enteritidis strain E6 (EU118106.1). The test bacterial isolates clustered with members of the genus Salmonella

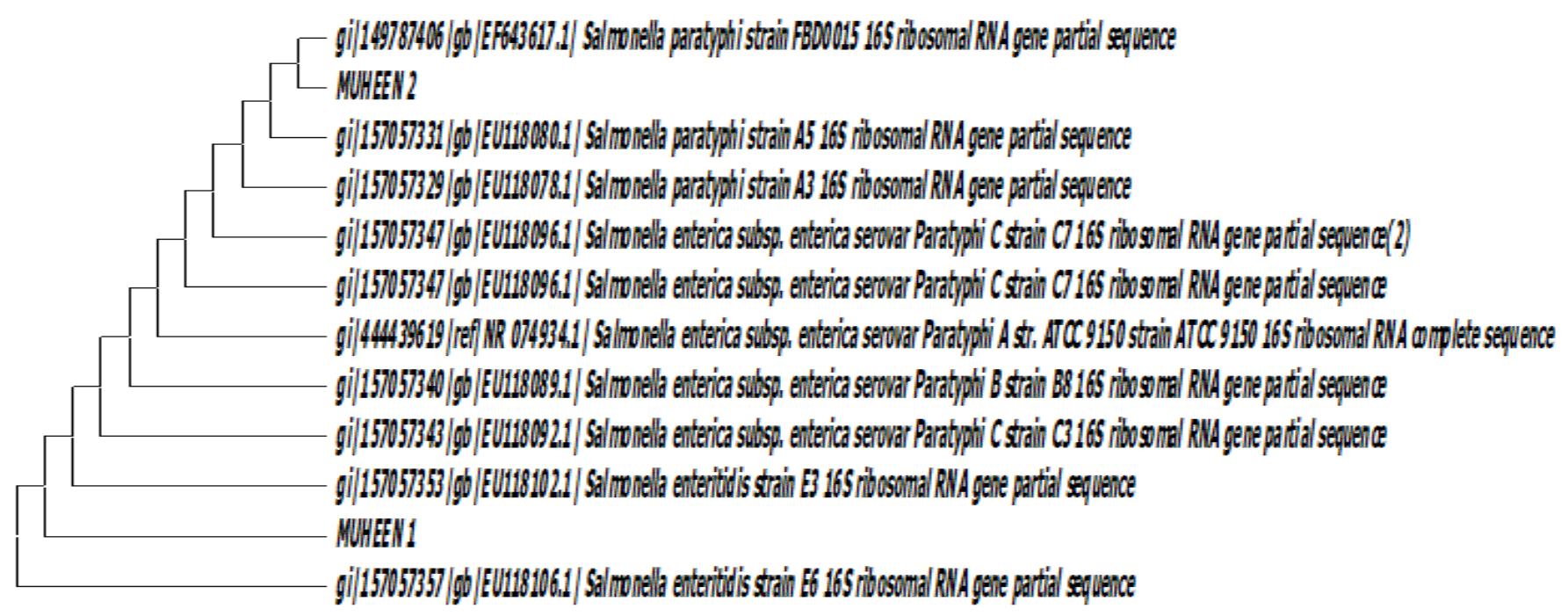

Figure-1. Phylogenetic tree constructed by Neighbor-Joining method derived from analysis of the $16 \mathrm{~S}$ rRNA gene sequences of native isolates and related sequences obtained from NCBI. Source: GenBank: Lus AE006468 NCBI, ncbi.nlm.nih gov:

\section{Discussions}

The prevalence rate of Salmonella detected was 3.5\% among three intensive poultry farms studied. The prevalence may be regarded as low compared with prevalence rates of $18.4 \%$ reported in Kaduna, Nigeria by Mbuko, et al. [12] 9.4\% reported at Jos, Nigeria by Okwori, et al. [13] and $11 \%$ of fowls reared at intensive poultry farms in Ibadan, Nigeria by Fashae, et al. [4]. The low incidence in this study might be attributed to high standard of hygiene employed by these farmers and record of constant visit to the farms by veterinary doctors. The farms also have boreholes as source of water supplied that may minimize fowl infections through water source.

In this study two species of Salmonella were isolated, Salmonella Enteritidis and Salmonella Paratyphi. In Africa, as well as elsewhere in the world, Salmonella Enteritidis and Salmonella Typhimurium are the most common causes of human salmonellosis [14]. Interestingly, only Salmonella Enteritidis was recovered from the fecal dropping of laying birds in our study, but Salmonella Typhimurium was not detected. However, in similar study in 
Burkina Faso, the main serotype found in poultry, animal and human fecal samples were Salmonella Typhimurium and Salmonella Muenster (from all the animal species) $[15]$.

Previous study on PFGE provides valuable phylogenetic relationship inference for Salmonella at serovar level [16]. In this study, phylogenetic tree constructed by neighbor-joining method as derived from analysis of the $16 \mathrm{~S}$ rRNA gene sequences showed close relationship among Salmonella Paratyphi strain FBoo15 16S ribosoma RNA gene partial sequence to our Salmonella Paratyphi isolates. Similarly our Salmonella Enteritidis is closely related to Salmonella Enteritidis stain ES $16 \mathrm{~S}$ ribosomal RNA and Salmonella Enteritidis strain E6 16S ribosomal RNA obtained from NCBI (Figure 1). This genetic relatedness was $99 \%$ and $100 \%$ of Salmonella Enteritidis and Salmonella Paratyhi to our isolated Salmonella Enteritidis and Salmonella Paratyphi respectively.

Salmonella Enteritidis and Salmonella Paratyphi are readily transmitted from egg and poultry meat to human with health consequences Kingsley, et al. [17]. Report by Acha and Szyfres [1] stated that 60-80\% of all Salmonelosis cases are not recognized as part of a known outbreaks and classified as sporatic cases or are not diagnosed as such at all.

Hygienic methods to be employed in poultry products handling to avoid transmission of infectious agents should include proper hand washing, personal hygiene of workers, properly boiling of poultry meat and egg before consumption. The use of poultry droppings as manure for improving crop yields especially vegetables that may be consumed raw should be discouraged. This is because Salmonella are hardy are able to survive several weeks in dry environment and several months in moisture condition and in water [1].

\section{Conclusion}

This study revealed detection of Salmonella Enteritidis and Salmonella Paratyphi in poultry drooping of intensive farms in Ilorin, Nigeria, however with low prevalence. The isolated strains were genetically related to human strain. Carriage of Salmonella in poultry dropping is a potential source of acquisition of infection by human. We therefore suggest systematic surveillance of poultry farms by health experts and discourage in use of poultry droppings as manure for vegetables that are not cooked before consumption.

\section{References}

[1] P. N. Acha and B. Szyfres, Zoonoses and communicable diseases common to man and animals: Parasitic zoonoses vol. 580: Pan American Health Org, 2013.

[2] B. E. Gillespie, A. G. Matthew, F. A. Draughon, B. M. Jayarao, and S. P. Oliver, "Detection of salmonella enterica somatic group CI and EI by PCR-Enzyme-linked Immunosorbent Assay (ELISA)," Journal of Food Protection, vol. 66, pp. 2367-2370, 2003. View at Google Scholar | View at Publisher

[3] A. Kagambega, T. Lienemann, L. Aulu, A. S. Traore, N. Barro, A. Siilonen, and K. Haukka, "Prevalence and characterization of Samonella enterica from the feces of cattle, poultry, swine and hedgehogs in Burkina Faso and their comparison to human Salmonella isolates," BMC Microbiology, vol. 13, pp. 253-266, 2013. View at Google Scholar | View at Publisher

[4] K. Fashae, F. Ogunsola, M. A. Frank, and R. S. Hendriksen, "Antimicrobial susceptibility and serovars of Salmonella from chickens and Humans in Ibadan, Nigeria," Journal of Infection in Developing Countries, vol. 4, pp. 484-494, 2010. View at Google Scholar | View at Publisher

[5] P. Antunes, C. Reu, J. C. Scusa, L. Peixe, and N. Pestana, "Incidence of salmonella from poultry products and their susceptibility to antimicrobial agents," International Journal of Food Microbiology, vol. 82, pp. 97-103, 2003. View at Google Scholar |View at Publisher

[6] B. A. Forbes, D. F. Sahn, and A. S. Weissfield, In: Bailey and Scott's diagnostic microbiology masha: Elsevier, 2007.

[7] G. I. Barrow and R. K. A. Feltham, In: Cowan and steel's manual for the identification of medical bacteria: Cambridge University Press, 1993.

[8] A. Heddi, A. M. Grenier, C. Khatchadourian, H. Charles, and P. Nardon, "Four intracellular genomes direct weevil biology: Nuclear, mitochondrial, principal endosymbiont, and wolbachia," in Proceeding of the National Academic of Science (USA), 1998, pp. 6814-6819.

[9] S. F. Altschul, T. L. Maddan, A. A. Schaffer, J. Zhang, Z. Zhang, W. Miller, and D. J. Lipman, "Gapped BLAST and PSI-BLAST: A new generation of protein database search programs," Nucleic Acids Research, vol. 25, pp. 3389-3402, 1997. View at Google Scholar | View at Publisher

[10] J. D. Thompson, D. G. Higgins, Gibson, and W. Clustal, "Improving the sensitivity of progressive multiple sequence alignment through sequence weighting, position-specific gap penalties and weight matrix choice," Nucleic Acids Research, vol. 22, pp. 46734680, 1994. View at Google Scholar |View at Publisher

[11] K. Tamura, J. Dudley, M. Nei, and S. Kumar, "MEGA4: Molecular evolutionary genetics analysis (MEGA) software version 4.0," Molecular Biology and Evolution, vol. 24, pp. 1596-1599, 2007. View at Google Scholar | View at Publisher

[12] I. J. Mbuko, M. A. Raji, J. Ameh, L. Saidu, W. L. Musa, and P. A. Abdual, "Prevalence and seasonality of fowl typhoid disease in Zaria-Kaduna State, Nigeria," Journal of Bacteriology Research, vol. 1, pp. 001-005, 2009. View at Google Scholar

[13] A. E. Okwori, G. A. Hasimil, J. A. Adetunji, I. O. Akaka, and S. A. Junards, "Serological survey of salmonella gallinarum antibodies in chicken around Jos, Plateau State, Nigeria," Online Journal of Health and Allied, vol. 6, 2007. View at Google Scholar

[14] R. S. Hendriksen, A. R. Vieira, S. Karlsmose, F. O. Lo, D. M. Wong, A. B. Jense, H. C. Wegener, and F. M. Aarestrup, "Global monitoring of salmonella serovar ddistribution from the world health organization global foodborne infections network country data bank; results of quality assured laboratories from 2001-2007," Foodborne Pathogens and Disease, vol. 8, pp. 887-900, 2011. View at Google Scholar | View at Publisher

[15] W. H. Andrew and T. S. Hammack, "Salmonella. Bacteriology analytical manual online chapter 5," 1998.

[16] H. Harbottle, D. G. White, P. F. McDermott, R. D. Walker, and S. Zhao, "Comparison of multilocus sequence typing, pulsed-field gel electrophoresis, and antimicrobial susceptibility typing for characterization of salmonella enterica serotype newport isolates," Journal of Clinical Microbiology, vol. 44, pp. 2440-2457, 2006. View at Google Scholar | View at Publisher

[17] R. A. Kingsley, C. L. Msefala, N. R. Thomso, S. Kariukis, K. E. Holt, M. A. Gordan, D. Harris, L. Clarke, S. Whitehead, V. Sangal, K. Marsh, M. Achtman, M. E. Molyneux, M. Cormican, J. Parkhill, C. A. Maclennan, R. S. Heyderman, and G. Dougan, "Epidemic multiple drug resistant samonella typhimurium causing invasive disease in Sub-Saharan Africa have a distinct genotype," Genome Research, vol. 19, pp. 2279-2287, 2009. View at Google Scholar | View at Publisher 